\title{
ANÁLISE COMPARATIVA DE MÉTODOS PARA RESOLVER O PROBLEMA DE PROGRAMAÇÃO DE TRIPULAÇÕES
}

\section{COMPARATIVE ANALYZE OF METHODS TO SOLVE THE BUS CREW SCHEDULING PROBLEM}

\author{
Gustavo Peixoto Silva \\ Professor Doutor \\ Universidade Federal de Ouro Preto \\ Departamento de Computação \\ ICEB - Campus Universitário Morro do Cruzeiro \\ (31) 3559-1645 - gustavo@iceb.ufop.br

\section{Marcone Jamilson Freitas Souza} \\ Professor Doutor \\ Universidade Federal de Ouro Preto \\ Departamento de Computação \\ ICEB - Campus Universitário Morro do Cruzeiro \\ (31) 3559-1658 - marcone @ iceb.ufop.br \\ Jorge von Atzingen \\ Engenheiro \\ Universidade de São Paulo \\ Departamento de Engenharia de Transportes \\ POLI/USP - Escola Politécnica \\ (11) 3091-5732 - jatzingen@ gmail.com
}




\title{
RESUMO
}

Este trabalho trata do Problema da Programação de Tripulações (PPT), o qual visa determinar um conjunto de jornadas de trabalho para as tripulações de menor custo e tal que a programação dos veículos seja realizada com sucesso. Como restrição, cada jornada deve atender à legislação trabalhista do setor. Neste trabalho são comparados quatro diferentes métodos de geração e seleção de colunas, sendo que cada coluna corresponde a uma jornada para o PPT. No primeiro método são geradas colunas considerando intervalos de tempo, ao longo do dia, nos quais pode ocorrer a troca de tripulações. No segundo, as jornadas geradas apresentam um dado tempo mínimo de duração. No terceiro método é implementada a heurística de Chvátal, a qual seleciona colunas para o PPT. O quarto método combina o segundo e o terceiro métodos. São apresentados resultados comparativos com dados reais, mostrando a possibilidade da utilização prática desses métodos em casos brasileiros.

Palavras-chave: Escala de motoristas e cobradores, Programação de tripulações, Geração de colunas.

\begin{abstract}
This work approaches the Bus Crew Scheduling Problem (BCSP), which aims to determine a set of workdays to the crews with the minimum operational cost, so that the vehicle scheduling could be performed. The constraints of this problem should comply with the labor agreement. In this paper it is presented and compared four different methodologies of columns generation for the BCSP, defining as these problems of Integer Linear Programming with binary variables. The first methodology consists of determining a time interval during which can happen the crew's exchange. In the second methodology the journey have at least a minimum time length. In the third methodology the Chvátal's heuristics is implemented. The fourth methodology presents the implementation of a hybrid method of columns generation for the BCSP. In this paper, comparative results from real-world problems are presented, showing the possibility of utilizing such methods in practical brazilian cases.
\end{abstract}

Key-words: Crew scheduling, Drivers scheduling, Column generation.

\section{INTRODUÇÃO}

O Problema de Geração da Escala de Tripulações no Sistema de Transporte Coletivo por Ônibus Urbano é denominado no meio científico de Problema da Programação de Tripulações (PPT). O problema consiste em determinar o número mínimo necessário de tripulações (motoristas e cobradores), tal que a programação dos veículos, ou seja, o conjunto de viagens atribuídas a cada veículo da frota em operação, seja realizada com sucesso. A solução deste problema também envolve o seqüenciamento das atividades de cada tripulação, gerando um conjunto de jornadas de trabalho, denominado de escala das tripulações, cujo 